\title{
The Hidden Cost of Supply Chain Disruptions: Case Study of the UK's Automotive Sector
}

\author{
https://doi.org/10.21272/sec.4(3).5-19.2020.
}

Hubert Escaith, ORCID: https://orcid.org/0000-0001-6936-3377

Visiting scholar, Shanghai University of International Business and Economics (SUIBE); Associate researcher at Aix-Marseille University (Aix-Marseille School of Economics), CNRS \& EHESS; Former WTO Chief Statistician, Spain

Sangeeta Khorana, ORCID: $\underline{\text { https://orcid.org/0000-0001-8901-0050 }}$

$\mathrm{PhD}$, Professor of Economics, Business School, Executive Business Centre, Bournemouth University, Bournemouth, UK

William A. Kerr, ORCID: https://orcid.org/0000-0001-5716-6261

$\mathrm{PhD}$, Department of Agricultural and Resource Economics, College of Agriculture and Bioresources University of Saskatchewan, Canada

\begin{abstract}
As the world economy has become increasingly integrated the spectre of transnational supply chains has become a central feature of globalisation. The smooth and unfettered working of transnational supply chains has facilitated efficiency increasing changes to business operations (such as just in time inventory management). The automotive sector worldwide has been at the forefront of internationally integrated supply systems. The European Union (EU) has, in part, been structured to reduce friction in Europe-wide supply chains through the single market. Transnational supply chains are at the heart of United Kingdom (UK) - EU trade, and the UK's departure from the EU's single market (Brexit) will increase friction in international trade. This case study of the UK's automotive sector uses a social network approach to analyse supply chain linkages between the UK, EU and other trading partners, and how these could be impacted as a result of Brexit. We use data from Trade in Value Added (TiVA) and World Input-Output Database (WIOD) to map supply chains, estimate total value-added in exports and examine how Brexit is likely to impact the competitiveness of UK exports. Results confirm that the UK's automotive sector is closely integrated with the EU. To offset the loss of UK's export competitiveness after Brexit, trade facilitation measures complemented with a duty drawback scheme could be an option in the short run. Policy measures are, however, unlikely to replace the benefits of duty-free and frictionless access enjoyed under single market trading arrangements. This suggests that the UK automotive sector, which is primarily comprised of globally active firms, may have to reconfigure supply chain arrangements and in the long run alter how decisions pertaining to locations are made.
\end{abstract}

Keywords: Brexit, global value chains, input-output linkages, WIOD.

JEL Classification: F13, F10, F47, F62.

This work is licensed under a Creative Commons Attribution 4.0 International License.

Cite as: Escaith, H., Khorana, S., Kerr, W.A. (2020). The Hidden Cost of Supply Chain Disruptions: Case Study of the UK's Automotive Sector. SocioEconomic Challenges, 4(3), 5-19. https://doi.org/10.21272/sec.4(3).5-19.2020.

(C) The Authors, 2020. This article is published with open access at Sumy State University.

\section{Introduction}

Global value chains (GVCs) involve production where the output of a firm in one country is used by another firm in second country to produce a more complex product which, in turn, may be used by another firm for further processing before being consumed as the final product (World Bank et al. 2019). While trade under GVCs has become increasingly complex and internationalised (Baldwin, 2006; Grossman \& Rossi-Hansberg, 
2008) trade through supply chains have resulted in greater efficiency and lower costs (Antràs and Gortari 2018; World Bank, 2020). Transnational supply chains are at the heart of EU-UK trade so much so that nearly $50 \%$ of UK's intermediate imports and exports are with EU member states (Department for International Trade, 2019). Further, intermediate goods and services account for a majority of both the UK's imports from and its exports to the EU (Levell, 2018). There is considerable academic literature on the effect of Brexit on the UK and implications for global trade, and while the precise cost of UK leaving the EU is unknown it is certain that GVCs that connect the UK - EU trade will be disrupted. In addition to Brexit, the COVID-19 pandemic has further brought the GVC interconnectedness and interdependence to the forefront, illustrating how export competitiveness is dependent on the sourcing of inputs and on access to final producers and consumers in third countries - an issue that we examine.

Our paper contributes to existing literature in the following ways: first, it provides quantitative information on the position of UK's exports and imports in GVCs, calculates the revealed comparative advantage (RCA) of exports, estimates the domestic and foreign content embodied in exports, as well as the degree of employment embeddedness. Existing literature on Brexit examines the overall expected trade and economic effects (e.g. Ali-Yrkkö and Kuusi, 2019; Cappariello et al., 2019; Gasiorek et al., 2019; Chen et al., 2018; Ijtsma et al., 2018; HMG, 2018; Borchert and Tamberi, 2018; Wyman, 2018; Portuese, 2018; Clarke et al. 2017; Vandenbussche et al., 2017; Bailey and Propris, 2017; Brakman et al., 2017), and there are some sector specific studies (see Lobao and Santos, 2018; Bailey and Propris, 2017). Although Bailey and Propris (2017) examine the impact of Brexit on the UK's automobile manufacturing sector this study examines short-run impacts and the effect of uncertainty on foreign direct investment (FDI) inflows and firm specific impacts. There are several studies that focus on the automobile industry (see for example, Xu and Liu, 2018; Rakita et al., 2017; Shende, 2014). Some highlight the high levels of competition and identify technological innovations as a driver of changes in this sector (Xu and Liu, 2018; Shende, 2014) Oher studies focus on how the global economic crisis and report that the 2008 crises had a strong impact on the global automobile industry (Rakita et al., 2017). Our paper uses the Organisation of Economic and Cooperation Development (OECD)-WTO Trade in Value-Added (TiVA) database ${ }^{1}$ and World Input-Output Data (WIOD) on Inter-Country InputOutput (ICIO) tables for 2000-14 to provide an insight into the expected impact on the automotive sector. Another contribution of this paper is a detailed insight into the implications for future UK trade policy, which is particularly relevant in light of the COVID-19 pandemic and the UK's departure from the EU at the end of 2020.

The paper is structured as follows: section two provides an overview of the supply chain linkage literature and the linkages of UK supply chains; section three draws attention to how the UK's automobile sector is likely to be impacted by Brexit; section four examines the impact of Brexit on UK's export competitiveness; section five concludes.

\section{Relevant literature and methodology}

\subsection{Characterising supply chains}

Globalisation has been characterised by increasing complexity of value chain relationships that entail diverse sources of inputs and multi-country distribution channels emanating from and terminating in points of manufacture. To examine the ramifications of these complex GVCs has required moving beyond neo-classical economic analysis into the realm of new institutional economics, transaction costs and supply chain management into a network analysis that examines complex interlinkages between countries (Hobbs, 1996). Kano et al. (2020) conduct an exhaustive review based on a comparative institutional perspective that encompasses critical governance issues at the micro- and macro-levels. Earlier literature debates the evolution of supply chains, and the impact on production of trade links between countries leading to an increasingly dense international trade network of intermediate inputs that include parts and components, natural resources and business services (Gereffi et al., 2005; UNCTAD, 2013; OECD, 2012; Nielson et al., 2014; Coe and Yeung, 2015; WTO, 2017). The evolution of GVCs and impact on production from GVCs links between countries has been examined through the lens of an increasingly dense international network of intermediate inputs that include parts and components, natural resources and services (Gereffi et al., 2005). Studies

\footnotetext{
${ }^{1}$ TiVA database, developed by the OECD-WTO, provides indicators on trade in value added for all OECD, EU-28 and G20 countries, most East and South-east Asian economies and a selection of South American countries.
} 
examining the impact of Brexit take the EU-UK GVCs into account and use different analytical frameworks. For example, Vandenbussche et al. (2017) estimate a gravity model in value added, featuring sector-level input-output production linkages. Pisani and Caffarelli (2018) develop a dynamic model with tradeable intermediate goods and services (as well as intermediate non-tradeable services) calibrated for the euro area and the UK, and assess the effects of alternative tariff scenarios. ${ }^{2}$ Baldwin and Lopez-Gonzalez (2013) suggest that the GVCs extend across the developed and developing countries, mainly in regional blocs, commonly called Factory Asia, Factory North America, and Factory Europe. Johnson and Noguera (2012) explain regionalisation by geographical distance that impacts value-added trade flows across countries.

The GVC literature is characterised under three strands: the first two are based on theoretical issues regarding supply chains, and the third comprises of empirical explorations. The first strand holds that increasingly complex supply chains are a sign of increased efficiency in the globalised system of production. It argues that comparative advantage is changing and that the change arises from the easing of trade in intermediate inputs (Baldwin, 2012; Ali and Durash, 2011). Blanchard et al. (2016) find that countries well integrated in GVCs exhibit lower tariff protection. The second strand takes a firm level approach and finds networked multinational firms have a growing importance in global trade (Keane, 2014). It has been found that lead firms (from China and India, in particular) have market power and are able to use that advantage in negotiations with suppliers, primarily those from developing countries (Bigsten et al., 2000; Gereffi et al. 2005; Nolan and Zhang, 2010; Milberg and Winkler, 2013; Nielson, 2014; Nadvi and Horner, 2018). The third stand of literature attempts to empirically disentangle the domestic and foreign content of countries' trade. The methods employed to examine inter-industrial networks, mainly input-output (IO) matrices, are in line with the vertical specialisation concept proposed by Hummels et al. (2001). Studies examining the position of countries within global production networks estimate the domestic value-added content of a bundle of exports, i.e. vertical specialisation (Baldwin and Lopez-Gonzalez, 2013; Timmer et al., 2014; Koopman, et al., 2014). Acemoglu et al. (2012) suggest the importance of network centrality and examine the cascade effect arising from a shock.

\subsection{Data and methodology}

This paper adapts social network approach to analyse GVC relationship between the UK and its trading partners. Escaith (2014) relates GVC decomposition with network analysis. Recent works by Ignatenko et al. (2019) and Ahmad (2019) use the GVC lens to examine the complex network structure of flows of goods, services, capital and technology across national borders. Koopman et al. (2014) propose the decomposition of total gross exports by source and destination of the embedded value added. Borin and Mancini (2017) introduce the 'follow-the-value-added' methodology that refines and corrects Koopman et al. (2014) analysis, making possible a proper investigation of the bilateral, as well as sectoral, dimension of trade flows and an analysis of a country's backward and forward linkages within the GVC.

Data for our paper are taken from the OECD-WTO TiVA database that reports value-added data on 62 countries for 12 sectors of goods and services (see Annex table A.1 for sector aggregation). We also use the World Input-Output Data (WIOD) with annual world IO tables for 2000-14 (2016 release) and UNCOMTRADE bilateral trade data to map supply chain linkages (inputs and finished) to trace the origin (sectoral and geographic) of the value-added embodied in goods and services. Finally, the decomposition of employment provided by an economy through exports draws on Miroudot (2016), which matches classifications and business functions for 37 countries between 1995-2013. The average tariffs, on intermediate and final goods traded between the EU and the UK, are based on the methodology developed in Cappariello (2017). We compute the indirect costs of tariffs following the works of Miroudot et al. (2013).

We derive a set of network indicators such as revealed comparative advantage (RCA), economic weight, connections between countries as measured by indegree and outdegree (i.e. the number of trade flows pointing to or from a node weighted by trade flows), eigenvector centrality (measure of distance between a country and farthest trade partner) and PageRank - a probabilistic score based on a hierarchy of nodes by link popularity and where a node is ranked higher if there are more links pointing to it.

\footnotetext{
${ }^{2}$ Other interesting studies on Brexit are Dhingra et al. (2017) and OECD (2016), which do not explicitly feature GVCs, and RojasRomagosa (2016).
} 
The RCA is 'revealed' because the calculation of comparative advantages is based on trade statistics: if a country has a comparative advantage in a given product it will specialise in exporting it. An RCA of 1 indicates a neutral position, i.e. the country's export specialisation corresponds to the weight of this product in world trade; whereas scores higher/lower than 1 indicate an advantage/disadvantage in exporting the product. The RCA does not explain value chains given intermediate products are linked through a country's production function. Product-space is based on a statistical association (correlation) that is based on similar know-how and resource endowments. This is based on the information provided by the Atlas of Economic Complexity (or "Atlas").

Indegree and Outdegree are trade flows pointing to or from a given node and weighted by trade flows (value of imports and exports). The weighted degree is the sum of imports plus exports.

Betweenness centrality and eigen centrality provides an indication of partners' dominance and influence (centrality). A country with higher betweenness centrality is likely to have more control over its trade network, due to higher trade flows. As Borgatti $(2005$, p. 61) states "the idea is that even if a node influences just one other node, that subsequently influences many other nodes (that influence others), then the first node in that chain is highly influential."

PageRank is a probabilistic score based on a hierarchy of node by 'link popularity'. This is closely associated with eigen centrality. Basically, a node is ranked higher suggesting the influence extends beyond direct connections with the wider network. The PageRank score for a country is based on the probability that trade flows will go through the country. The rank value indicates the importance and "centrality" of a particular country as a trade hub. This importance can be related to the economic size, but also highlights the trading relationship with other trading partners.

\section{UK' s trade-based supply chains}

The UK ranks tenth and fourth as an exporter and importer in global trade. Exports and imports are valued at approximately $£ 661.7$ and $£ 629.4$ billion, respectively. In 2015, 44 percent of UK exports were to the EU, and approximately 53 percent of total UK imports originated in EU countries (WTO, 2017). The pattern of trade interdependence is evident from UK's imports from the EU - 52 percent compared to 22 percent from the next three most important countries combined - China (9\%), USA (9\%) and Switzerland (4\%). Table 1 shows the importance of inputs and finished goods produced and traded by the UK.

Table 1. UK's position in World Trade Network: selected indicators, 2014

\begin{tabular}{|l|c|c|c|c|c|c|}
\hline \multicolumn{1}{|c|}{ Sectors by TiVA database } & $\begin{array}{c}\text { Eigen } \\
\text { centrality }\end{array}$ & $\begin{array}{c}\text { Weight } \\
\text { indegree }\end{array}$ & $\begin{array}{c}\text { Weight } \\
\text { outdegree }\end{array}$ & Weight degree & PageRank & $\begin{array}{c}\text { Betweenness } \\
\text { centrality }\end{array}$ \\
\hline Agriculture (C01T05) & 0.653 & 13044 & 4571 & 17615 & 0.003238 & 0.00004 \\
\hline Mining (C10T15) & 0.343 & 37315 & 36045 & 73361 & 0.001582 & 0.000075 \\
\hline Agroindustry (C15T16) & 0.878 & 55634 & 19250 & 74885 & 0.004243 & 0.000004 \\
\hline Textiles (C17T19) & 0.859 & 34314 & 11366 & 45681 & 0.004446 & 0.000008 \\
\hline Wood and Paper(C30T22) & 0.653 & 20147 & 15159 & 35306 & 0.003991 & 0.000024 \\
\hline Chemicals (C23T26) & 0.896 & 114647 & 96489 & 211136 & 0.003107 & 0.000007 \\
\hline Metals (C27T28) & 0.728 & 40918 & 25928 & 66847 & 0.002792 & 0.000019 \\
\hline Electronics (C20T33) & 0.832 & 72831 & 38808 & 111639 & 0.003608 & 0.000013 \\
\hline Vehicles (C34T35) & 0.605 & 96128 & 69766 & 165895 & 0.005308 & 0.000034 \\
\hline $\begin{array}{l}\text { Transport, communication and } \\
\text { commerce (C50764) }\end{array}$ & 1.000 & 150009 & 132177 & 282186 & 0.003074 & 0.000001 \\
\hline Business services (C65T64) & 0.770 & 101150 & 197708 & 298859 & 0.004673 & 0.000013 \\
\hline $\begin{array}{l}\text { Health, education and administration } \\
\text { (C75T95) }\end{array}$ & 0.687 & 26733 & 28322 & 55056 & 0.006401 & 0.000015 \\
\hline
\end{tabular}

Source: Authors calculation based on TiVA data and Gephi software.

The UK dominates in services exports with a positive correlation between in-degree (importer) and out-degree (exporter) scores for services exports. Business services (C65T74) has strong export-weighted connectedness, while chemicals (C23T26) is largest in terms of its economic weight. The in- and out-degree weights are highest for cars/vehicles (C34T35) with a PageRank score of 0.00531 suggesting that the influence extends to beyond direct connections in the wider trade network. The sector's in- and out-degree weight 
connectedness is attributed to the strong integration of the British and European automotive industry through complex supply chains that rely on just-in-time delivery of components from Germany and France.

Product connectedness based on the revealed comparative advantage (RCA), calculated as a correlation between exports across countries enables identification of sectors with larger linkages to other sectors. The UK has a high RCA in financial services, mainly financial intermediation (C65T74). Figure 1 focusses on UK's main RCA clusters in manufactured goods - cars, aircrafts and turbines (i.e. transport and related machinery), and medicaments and chemicals. The RCA of 2.1 for cars is attributed to UK's integration and the reliance on pan-European supply chains for car components - approximately 80 percent of UK-imported automotive components came from the EU27 representing 16 percent of the export value of EU27 car parts and accessories. Further analysis shows that 60 percent of UK-built parts and accessories were exported to the EU27 in 2018, accounting for 18 percent of the total value of EU27 component imports.

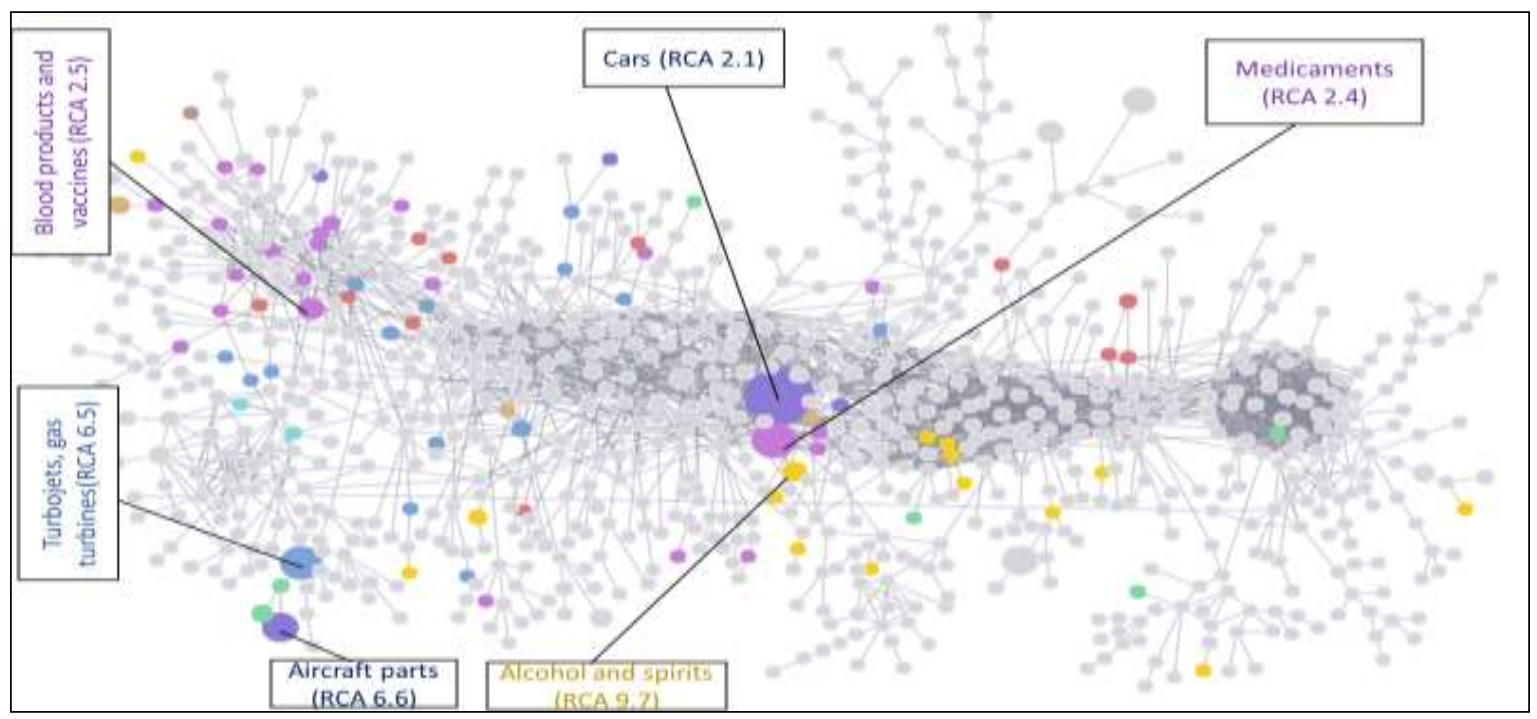

Figure 1. UK's Product space, 2016

Notes: The product space (by HS-4 digit classification) depicts connectedness between products, based on the similarities of endowments required to produce them. The RCA compares the share of a product in country's exports by the weight of product in world trade. Coloured nodes are products for which the RCA of UK is higher than 2.

Source: Atlas of Economic Complexity, Harvard Centre for International Development.

Despite a low RCA (0.73) in vehicles/cars the UK is an important exporter of transport equipment. The UK's RCA is indicative of the large share of value that is embodied in UK exports and is attributed to components imported from Germany and France. UK's imports include: Springs and leaves for springs; Other lifting, handling, loading or unloading machinery; Other articles of vulcanized rubber other than hard rubber; Parts and accessories of the motor vehicles: Safety glass, consisting of toughened (tempered) or laminated glass.

The decomposition of employment embodied in UK exports draws on Miroudot (2016) that matches occupation classifications and business functions for 37 countries between 1995-2013. Table 2 reports the composition of employment embodied in UK exports by sector and origin, and distinguishes between the destinations of exports for trade with all regions.

Table 2. Employment embodied in UK sectoral value added exports, 2011

\begin{tabular}{|c|c|c|c|c|c|c|c|}
\hline & \multicolumn{2}{|c|}{ World } & \multirow[b]{2}{*}{ EU } & \multirow[b]{2}{*}{ NAFTA } & \multirow{2}{*}{$\begin{array}{c}\text { East \& South } \\
\text { Asia }\end{array}$} & \multirow{2}{*}{$\begin{array}{c}\text { Central \& } \\
\text { South } \\
\text { America }\end{array}$} & \multirow{2}{*}{$\begin{array}{l}\text { Other } \\
\text { regions }\end{array}$} \\
\hline & Thousands & $\%$ & & & & & \\
\hline CTOTAL: TOTAL & 6588.2 & $100.0 \%$ & $43.0 \%$ & $19.2 \%$ & $11.1 \%$ & $1.9 \%$ & $24.8 \%$ \\
\hline $\begin{array}{l}\text { C01T05: Agriculture, hunting, } \\
\text { forestry and fishing }\end{array}$ & 87.3 & $1.3 \%$ & $0.8 \%$ & $0.1 \%$ & $0.1 \%$ & $0.0 \%$ & $0.3 \%$ \\
\hline C10T14: Mining and quarrying & 39.0 & $0.6 \%$ & $0.3 \%$ & $0.1 \%$ & $0.0 \%$ & $0.0 \%$ & $0.1 \%$ \\
\hline C15T37: Total Manufactures & 1296.0 & $19.7 \%$ & $7.9 \%$ & $3.4 \%$ & $2.3 \%$ & $0.4 \%$ & $5.7 \%$ \\
\hline $\begin{array}{l}\text { C15T16: Food products, beverages } \\
\text { and tobacco }\end{array}$ & 88.8 & $1.3 \%$ & $0.7 \%$ & $0.2 \%$ & $0.1 \%$ & $0.0 \%$ & $0.3 \%$ \\
\hline
\end{tabular}


Table 2 (cont.). Employment embodied in UK sectoral value added exports, 2011

\begin{tabular}{|c|c|c|c|c|c|c|c|}
\hline & \multicolumn{2}{|c|}{ World } & \multirow{2}{*}{$\begin{array}{c}\text { EU } \\
0.6 \%\end{array}$} & \multirow{2}{*}{\begin{tabular}{|c|} 
NAFTA \\
$0.1 \%$
\end{tabular}} & \multirow{2}{*}{\begin{tabular}{|c} 
East \& South \\
Asia
\end{tabular}} & \multirow{2}{*}{ 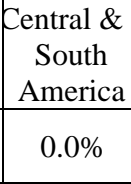 } & \multirow{2}{*}{$\begin{array}{l}\begin{array}{l}\text { Other } \\
\text { regions }\end{array} \\
0.2 \%\end{array}$} \\
\hline $\begin{array}{l}\text { C17T19: Textiles, textile products, } \\
\text { leather and footwear }\end{array}$ & 65.4 & $1.0 \%$ & & & & & \\
\hline $\begin{array}{l}\text { C20T22: Wood, paper, paper } \\
\text { products, printing and publishing }\end{array}$ & 136.4 & $2.1 \%$ & $1.0 \%$ & $0.3 \%$ & $0.2 \%$ & $0.0 \%$ & $0.5 \%$ \\
\hline $\begin{array}{l}\text { C20: Wood and products of wood and } \\
\text { cork }\end{array}$ & 17.4 & $0.3 \%$ & $0.1 \%$ & $0.0 \%$ & $0.0 \%$ & $0.0 \%$ & $0.1 \%$ \\
\hline $\begin{array}{l}\text { C21T22: Pulp, paper, paper products, } \\
\text { printing and publishing }\end{array}$ & 119.0 & $1.8 \%$ & $0.8 \%$ & $0.3 \%$ & $0.2 \%$ & $0.0 \%$ & $0.4 \%$ \\
\hline $\begin{array}{l}\text { C23T26: Chemicals and non-metallic } \\
\text { mineral products }\end{array}$ & 202.5 & $3.1 \%$ & $1.4 \%$ & $0.6 \%$ & $0.3 \%$ & $0.1 \%$ & $0.7 \%$ \\
\hline $\begin{array}{l}\text { C23: Coke, refined petroleum } \\
\text { products and nuclear fuel }\end{array}$ & 13.3 & $0.2 \%$ & $0.1 \%$ & $0.1 \%$ & $0.0 \%$ & $0.0 \%$ & $0.0 \%$ \\
\hline $\begin{array}{l}\text { C24: Chemicals and chemical } \\
\text { products }\end{array}$ & 101.9 & $1.5 \%$ & $0.6 \%$ & $0.3 \%$ & $0.2 \%$ & $0.0 \%$ & $0.4 \%$ \\
\hline C25: Rubber and plastics products & 64.3 & $1.0 \%$ & $0.4 \%$ & $0.2 \%$ & $0.1 \%$ & $0.0 \%$ & $0.2 \%$ \\
\hline $\begin{array}{l}\text { C26: Other non-metallic mineral } \\
\text { products }\end{array}$ & 22.9 & $0.3 \%$ & $0.2 \%$ & $0.1 \%$ & $0.0 \%$ & $0.0 \%$ & $0.1 \%$ \\
\hline $\begin{array}{l}\text { C27T28: Basic metals and fabricated } \\
\text { metal products }\end{array}$ & 167.8 & $2.5 \%$ & $0.9 \%$ & $0.4 \%$ & $0.3 \%$ & $0.1 \%$ & $0.9 \%$ \\
\hline C27: Basic metals & 46.5 & $0.7 \%$ & $0.2 \%$ & $0.1 \%$ & $0.1 \%$ & $0.0 \%$ & $0.3 \%$ \\
\hline C28: Fabricated metal products & 121.3 & $1.8 \%$ & $0.7 \%$ & $0.3 \%$ & $0.2 \%$ & $0.0 \%$ & $0.6 \%$ \\
\hline C29: Machinery and equipment, nec & 170.6 & $2.6 \%$ & $0.7 \%$ & $0.6 \%$ & $0.4 \%$ & $0.1 \%$ & $0.9 \%$ \\
\hline $\begin{array}{l}\text { C30T33: Electrical and optical } \\
\text { equipment }\end{array}$ & 198.5 & $3.0 \%$ & $1.1 \%$ & $0.6 \%$ & $0.4 \%$ & $0.1 \%$ & $0.8 \%$ \\
\hline $\begin{array}{l}\text { C30T33X: Computer, Electronic and } \\
\text { optical equipment }\end{array}$ & 136.0 & $2.1 \%$ & $0.8 \%$ & $0.5 \%$ & $0.3 \%$ & $0.0 \%$ & $0.5 \%$ \\
\hline $\begin{array}{l}\text { C31: Electrical machinery and } \\
\text { apparatus, nec }\end{array}$ & 62.5 & $0.9 \%$ & $0.3 \%$ & $0.2 \%$ & $0.1 \%$ & $0.0 \%$ & $0.3 \%$ \\
\hline C34T35: Transport equipment & 181.9 & $2.8 \%$ & $0.8 \%$ & $0.4 \%$ & $0.3 \%$ & $0.0 \%$ & $1.1 \%$ \\
\hline $\begin{array}{l}\text { C34: Motor vehicles, trailers and } \\
\text { semi-trailers }\end{array}$ & 67.6 & $1.0 \%$ & $0.4 \%$ & $0.2 \%$ & $0.1 \%$ & $0.0 \%$ & $0.3 \%$ \\
\hline C35: Other transport equipment & 114.2 & $1.7 \%$ & $0.4 \%$ & $0.3 \%$ & $0.1 \%$ & $0.0 \%$ & $0.9 \%$ \\
\hline $\begin{array}{l}\text { C36T37: Manufacturing nec; } \\
\text { recycling }\end{array}$ & 84.2 & $1.3 \%$ & $0.7 \%$ & $0.2 \%$ & $0.1 \%$ & $0.0 \%$ & $0.3 \%$ \\
\hline $\begin{array}{l}\text { C40T41: Electricity, gas and water } \\
\text { supply }\end{array}$ & 29.1 & $0.4 \%$ & $0.2 \%$ & $0.1 \%$ & $0.0 \%$ & $0.0 \%$ & $0.1 \%$ \\
\hline C45: Construction & 134.7 & $2.0 \%$ & $0.9 \%$ & $0.4 \%$ & $0.2 \%$ & $0.0 \%$ & $0.5 \%$ \\
\hline $\begin{array}{l}\text { C50T74: Total Business Sector } \\
\text { Services }\end{array}$ & 4434.0 & $67.3 \%$ & $28.9 \%$ & $13.7 \%$ & $7.8 \%$ & $1.3 \%$ & $15.7 \%$ \\
\hline $\begin{array}{l}\text { C50T55: Wholesale and retail trade; } \\
\text { Hotels and restaurants }\end{array}$ & 1492.5 & $22.7 \%$ & $9.6 \%$ & $4.1 \%$ & $2.7 \%$ & $0.5 \%$ & $5.8 \%$ \\
\hline $\begin{array}{l}\text { C50T52: Wholesale and retail trade; } \\
\text { repairs }\end{array}$ & 1300.5 & $19.7 \%$ & $8.3 \%$ & $3.6 \%$ & $2.4 \%$ & $0.4 \%$ & $5.0 \%$ \\
\hline C55: Hotels and restaurants & 191.9 & $2.9 \%$ & $1.3 \%$ & $0.5 \%$ & $0.3 \%$ & $0.1 \%$ & $0.7 \%$ \\
\hline $\begin{array}{l}\text { C60T64: Transport and storage, post } \\
\text { and telecommunication }\end{array}$ & 514.6 & $7.8 \%$ & $2.9 \%$ & $1.3 \%$ & $1.0 \%$ & $0.1 \%$ & $2.5 \%$ \\
\hline C60T63: Transport and storage & 380.3 & $5.8 \%$ & $2.0 \%$ & $0.9 \%$ & $0.7 \%$ & $0.1 \%$ & $2.1 \%$ \\
\hline C64: Post and telecommunications & 134.2 & $2.0 \%$ & $0.9 \%$ & $0.4 \%$ & $0.2 \%$ & $0.0 \%$ & $0.5 \%$ \\
\hline C65T67: Financial intermediation & 379.2 & $5.8 \%$ & $1.2 \%$ & $2.1 \%$ & $1.0 \%$ & $0.1 \%$ & $1.4 \%$ \\
\hline $\begin{array}{l}\text { C70T74: Real estate, renting and } \\
\text { business activities }\end{array}$ & 2047.8 & $31.1 \%$ & $15.2 \%$ & $6.2 \%$ & $3.2 \%$ & $0.5 \%$ & $5.9 \%$ \\
\hline C70: Real estate activities & 17.7 & $0.3 \%$ & $0.1 \%$ & $0.1 \%$ & $0.0 \%$ & $0.0 \%$ & $0.1 \%$ \\
\hline $\begin{array}{l}\text { C71: Renting of machinery and } \\
\text { equipment }\end{array}$ & 27.0 & $0.4 \%$ & $0.2 \%$ & $0.1 \%$ & $0.0 \%$ & $0.0 \%$ & $0.1 \%$ \\
\hline C72: Computer and related activities & 189.5 & $2.9 \%$ & $1.2 \%$ & $0.7 \%$ & $0.3 \%$ & $0.0 \%$ & $0.6 \%$ \\
\hline $\begin{array}{l}\text { C73T74: R\&D and other business } \\
\text { activities }\end{array}$ & 1813.6 & $27.5 \%$ & $13.7 \%$ & $5.4 \%$ & $2.8 \%$ & $0.5 \%$ & $5.2 \%$ \\
\hline $\begin{array}{l}\text { C75T95: Community, social and } \\
\text { personal services }\end{array}$ & 568.1 & $8.6 \%$ & $4.2 \%$ & $1.4 \%$ & $0.7 \%$ & $0.1 \%$ & $2.3 \%$ \\
\hline
\end{tabular}


Table 2 (cont.). Employment embodied in UK sectoral value added exports, 2011

\begin{tabular}{|c|c|c|c|c|c|c|c|}
\hline & \multicolumn{2}{|c|}{ World } & \multirow{2}{*}{$\begin{array}{c}\mathrm{EU} \\
0.3 \%\end{array}$} & \multirow{2}{*}{\begin{tabular}{|c|} 
NAFTA \\
$0.1 \%$
\end{tabular}} & \multirow{2}{*}{$\begin{array}{c}\begin{array}{c}\text { East \& South } \\
\text { Asia }\end{array} \\
0.1 \%\end{array}$} & \multirow{2}{*}{\begin{tabular}{|c}
$\begin{array}{c}\text { Central \& } \\
\text { South } \\
\text { America }\end{array}$ \\
$0.0 \%$
\end{tabular}} & \multirow{2}{*}{$\begin{array}{l}\text { Other } \\
\text { regions }\end{array}$} \\
\hline $\begin{array}{l}\text { C75: Public admin. and defence; } \\
\text { compulsory social security }\end{array}$ & 42.5 & $0.6 \%$ & & & & & \\
\hline C80: Education & 134.1 & $2.0 \%$ & $0.7 \%$ & $0.4 \%$ & $0.2 \%$ & $0.1 \%$ & $0.6 \%$ \\
\hline C85: Health and social work & 19.0 & $0.3 \%$ & $0.1 \%$ & $0.1 \%$ & $0.0 \%$ & $0.0 \%$ & $0.1 \%$ \\
\hline C90T95: Other social services & 372.5 & $5.7 \%$ & $3.0 \%$ & $0.8 \%$ & $0.3 \%$ & $0.1 \%$ & $1.5 \%$ \\
\hline $\begin{array}{l}\text { C10T41: Industry (Mining, } \\
\text { Manufactures and Utilities) }\end{array}$ & 1364.2 & $20.7 \%$ & $8.4 \%$ & $3.6 \%$ & $2.3 \%$ & $0.4 \%$ & $6.0 \%$ \\
\hline $\begin{array}{l}\text { C45T95: Total Services including } \\
\text { Construction activities }\end{array}$ & 5136.8 & $78.0 \%$ & $33.9 \%$ & $15.5 \%$ & $8.7 \%$ & $1.4 \%$ & $18.5 \%$ \\
\hline C50T95: Total Services & 5002.1 & $75.9 \%$ & $33.0 \%$ & $15.1 \%$ & $8.4 \%$ & $1.4 \%$ & $17.9 \%$ \\
\hline $\begin{array}{l}\text { C50T64: Wholesale, retail, hotels, } \\
\text { restaurants, transport }\end{array}$ & 2007.0 & $30.5 \%$ & $12.5 \%$ & $5.4 \%$ & $3.6 \%$ & $0.6 \%$ & $8.3 \%$ \\
\hline $\begin{array}{l}\text { C65T74: Finance, Real Estate and } \\
\text { business services }\end{array}$ & 2427.0 & $36.8 \%$ & $16.4 \%$ & $8.3 \%$ & $4.1 \%$ & $0.6 \%$ & $7.4 \%$ \\
\hline
\end{tabular}

Note: The estimates, based on national industrial averages, could possibly over-estimate actual employment. While TiVA includes all firms, it is worth noting that export-oriented firms and first/second tier suppliers are usually larger and more efficient in the use of labour than domestic firms.

Source: OECD Trade in employment Data Set: Core Indicators.

The export producing sectors of the UK provided 6.6 million jobs, both directly and indirectly in 2011 . The business services sector led with 4.4 million (67\%) total employment against manufacturing that employed 1.3 million (20\% of total export-related employment) and primary sectors (agriculture plus mining) comprising only 2 percent; the remaining employment is in other sectors, mainly 'administration' and 'other services'. The financial intermediation and manufacturing sectors account for high employment in valueadded. This is reflected by the fact that the automobile manufacturing sector employs 82,000 people in the UK supply chain and just 2500 automotive suppliers add $£ 4.9$ billion in value-added every year.

Table 3 presents the sectoral distribution of UK employment supported by final foreign demand, i.e. the relative weight of value-added used to produce UK exports. Considerable variation exists across regions and industries that explain the differences in the final employment by UK's export sectors. $43 \%$ of total employment in the UK's export sectors is attributed to demand arising from the EU while $19 \%$ of total employment arises from demand originating from NAFTA (i.e. Canada, Mexico and USA). The remaining $11 \%$ is from East and South Asian countries. The EU demand for UK labour-related value-added is in low wage sectors, such as primary sectors and fuel unlike Asia, where demand is in value-added manufacturing and financial services.

Table 3. Sectoral distribution of UK employment supported by final foreign demand: 2011

\begin{tabular}{|c|c|c|c|c|c|}
\hline World & EU & NAFTA & $\begin{array}{c}\text { East \& } \\
\text { South Asia }\end{array}$ & $\begin{array}{c}\text { Central \& } \\
\text { South America }\end{array}$ & Other \\
\hline CTOTAL: TOTAL & $43 \%$ & $19 \%$ & $11 \%$ & $2 \%$ & $25 \%$ \\
\hline Of which & $100 \%$ & $100 \%$ & $100 \%$ & $100 \%$ & $100 \%$ \\
\hline C01T05: Agriculture, hunting, forestry and fishing & $58 \%$ & $11 \%$ & $7 \%$ & $1 \%$ & $23 \%$ \\
\hline C10T14: Mining and quarrying & $52 \%$ & $18 \%$ & $7 \%$ & $3 \%$ & $21 \%$ \\
\hline C17T19: Textiles, textile products, leather and footwear & $60 \%$ & $11 \%$ & $9 \%$ & $1 \%$ & $19 \%$ \\
\hline C23: Coke, refined petroleum products and nuclear fuel & $53 \%$ & $25 \%$ & $5 \%$ & $2 \%$ & $15 \%$ \\
\hline C24: Chemicals and chemical products & $42 \%$ & $21 \%$ & $11 \%$ & $3 \%$ & $23 \%$ \\
\hline C27T28: Basic metals and fabricated metal products & $35 \%$ & $17 \%$ & $12 \%$ & $2 \%$ & $34 \%$ \\
\hline C27: Basic metals & $30 \%$ & $16 \%$ & $14 \%$ & $2 \%$ & $38 \%$ \\
\hline C29: Machinery and equipment, nec & $28 \%$ & $22 \%$ & $14 \%$ & $3 \%$ & $34 \%$ \\
\hline C30T33: Electrical and optical equipment & $37 \%$ & $21 \%$ & $15 \%$ & $2 \%$ & $26 \%$ \\
\hline C30T33X: Computer, Electronic and optical equipment & $37 \%$ & $22 \%$ & $15 \%$ & $2 \%$ & $24 \%$ \\
\hline C31: Electrical machinery and apparatus, nec & $35 \%$ & $18 \%$ & $14 \%$ & $3 \%$ & $30 \%$ \\
\hline C34T35: Transport equipment & $30 \%$ & $16 \%$ & $10 \%$ & $2 \%$ & $41 \%$ \\
\hline C35: Other transport equipment & $23 \%$ & $17 \%$ & $9 \%$ & $1 \%$ & $50 \%$ \\
\hline C36T37: Manufacturing nec; recycling & $53 \%$ & $13 \%$ & $7 \%$ & $1 \%$ & $26 \%$ \\
\hline C60T63: Transport and storage & $34 \%$ & $15 \%$ & $13 \%$ & $2 \%$ & $36 \%$ \\
\hline
\end{tabular}


Table 3. Sectoral distribution of UK employment supported by final foreign demand: 2011

\begin{tabular}{|l|c|c|c|c|c|}
\hline \multicolumn{1}{|c|}{ World } & EU & NAFTA & $\begin{array}{c}\text { East \& } \\
\text { South Asia }\end{array}$ & $\begin{array}{c}\text { Central \& } \\
\text { South America }\end{array}$ & Other \\
\hline C65T67: Financial intermediation & $20 \%$ & $36 \%$ & $17 \%$ & $2 \%$ & $25 \%$ \\
\hline C72: Computer and related activities & $43 \%$ & $24 \%$ & $11 \%$ & $1 \%$ & $20 \%$ \\
\hline C80: Education & $36 \%$ & $21 \%$ & $12 \%$ & $3 \%$ & $28 \%$ \\
\hline C85: Health and social work & $39 \%$ & $22 \%$ & $10 \%$ & $2 \%$ & $26 \%$ \\
\hline C90T95: Other social services & $54 \%$ & $14 \%$ & $6 \%$ & $1 \%$ & $26 \%$ \\
\hline C65T74: Finance, Real Estate and business services & $45 \%$ & $23 \%$ & $11 \%$ & $2 \%$ & $20 \%$ \\
\hline
\end{tabular}

Note: Highlighted sectors (red shade) based on the 5 largest source of UK employment by importing region.

Source: Sectoral value added based on OECD data.

Given the current supply chain interlinkages between the EU and UK, Brexit and COVID-19 are likely to rebalance value chains and affect the level of employment in UK's export sectors. The effect will, however, not be limited to EU demand but also that of other countries.

\section{Case study: UK's automotive sector}

The automotive industry in the UK is the heavily integrated into the EU's single market. The industry contributes $4 \%$ of UK's GDP and the labour employed accounts for more than $10 \%$ of total employment in the manufacturing sector (approximately 325,000 workers) (ACEA, 2019). As a member of the EU's single market zero tariffs apply. The departure of the UK from the single market and customs union could result in the automobile industry facing most favoured nation (MFN) tariffs under WTO commitments at $10 \%$ on cars and $2-4 \%$ on components. Estimates predict that leaving the EU without an arrangement on 'vehicles and parts thereof' could see tariffs of $£ 1.3$ billion applied to UK automotive exports, and of $£ 3.9$ billion applied by the UK on similar imports from the EU (Protts, 2016). This is expected to increase average car prices by over $£ 2,000$ (Ruddick, 2017).

Table 4 shows that the UK ranks fourth as an import market after the US, Germany and China. Centrality indicators confirm that UK plays a key role as importer for many countries covered by TiVA. PageRank score of 0.0053 illustrate the deep integration of the UK with the EU manufacturing supply chain suggesting that any disruption to the current trade relationship will feed back through the UK economy.

Table 4. Transport equipment: network indicators for top 10 importers, 2014

\begin{tabular}{|c|c|c|c|c|c|c|}
\hline Reporter & In-Degree & Out-Degree & $\begin{array}{c}\text { Betweenness } \\
\text { Centrality }\end{array}$ & $\begin{array}{c}\text { Closeness } \\
\text { Centrality }\end{array}$ & $\begin{array}{c}\text { Eigenvector } \\
\text { Centrality }\end{array}$ & PageRank \\
\hline USA & 291306 & 171154 & 0.00004 & 1.00 & 0.6142 & 0.0136 \\
\hline DEU & 121365 & 241680 & 0.00003 & 1.00 & 0.6056 & 0.0067 \\
\hline CHN & 111846 & 63508 & 0.00001 & 1.00 & 0.5587 & 0.0046 \\
\hline GBR & 96129 & 69767 & 0.00003 & 1.00 & 0.6050 & 0.0053 \\
\hline CAN & 87553 & 68855 & 0.00003 & 1.00 & 0.5987 & 0.0053 \\
\hline FRA & 78403 & 93855 & 0.00004 & 1.00 & 0.6142 & 0.0046 \\
\hline MEX & 58511 & 99505 & 0.00002 & 0.97 & 0.5912 & 0.0037 \\
\hline RUS & 39545 & 585 & 0.00001 & 0.89 & 0.5720 & 0.0017 \\
\hline ITA & 38163 & 42935 & 0.00003 & 1.00 & 0.5974 & 0.0018 \\
\hline ESP & 35922 & 49398 & 0.00003 & 1.00 & 0.6076 & 0.0018 \\
\hline
\end{tabular}

Notes: The reporters are ranked according to their In-degree score. Bilateral flows are weighted by the share of the bilateral flow in total vehicle exports of the reporter; bilateral flows smaller than $1 \%$ of reporter's exports were not considered in the calculation of network indicators.

Source: Authors calculations based on OECD TiVA Nowcasts.

The foreign value added embodied in manufactured exports at the bilateral level shows that the non-EU countries are important export destinations for UK transport equipment (42\% compared to $25.5 \%$ to EU27 members). Thus, the UK's importance as an export market is $18.6 \%$ to non-EU members, compared to $15.4 \%$ for EU-27 members (Figure 2). 


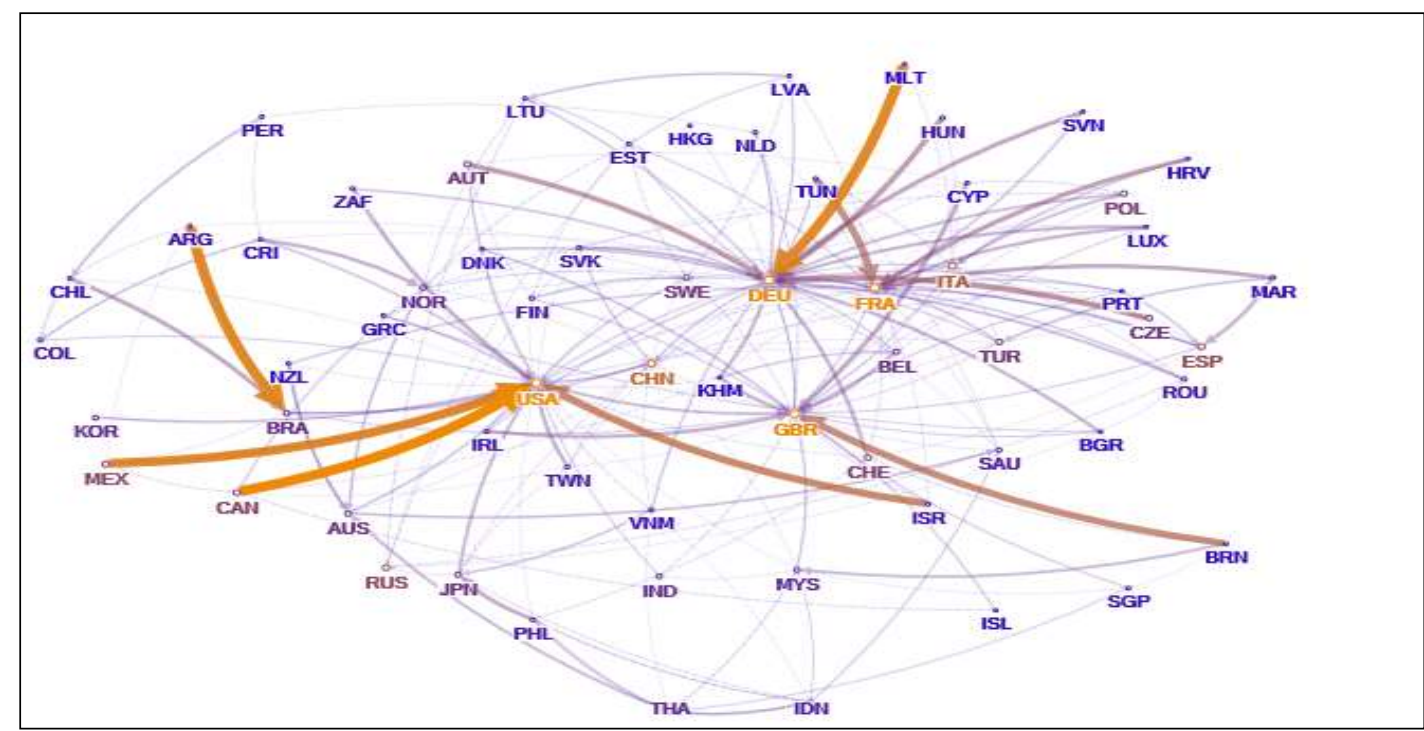

Figure 2. Trade in transport equipment, weighted by share in reporting country's exports, 2014

Note: Arcs (exports) are weighted (size and colour, from blue to red) by the share of the bilateral flow in total vehicle exports of the reporting country; bilateral flows smaller than $1 \%$ of reporter's exports were not considered in the calculation of network indicators and exports smaller than $3 \%$ are not shown. Nodes (import markets) are coloured by the in-degree score from blue (low score) to red (high score).

Source: Author's calculation based on TiVA Nowcast data.

The bilateral market shares of UK and Germany are both $10 \%$ for transport equipment, and the UK is an important export market for France and Italy than these countries are for UK exports. The impact of Brexit on the UK automobile sector will vary across regions and countries. Given that the weight of the UK as an export market for parts and components is high for smaller EU countries, such as Cyprus (29\%), Ireland (27\%), Belgium (26\%) and Denmark (17\%), the relative burden of UK tariffs on EU imports after the UK leaves the EU in December 2020 would be particularly high for the EU countries listed above.

Figure 3 shows that the share of domestic value-added in transport equipment exports (direct and indirect) in the UK is over $60 \%$ while the indirect value-added represents $54 \%$ of the domestic value-added. When UK is compared to Germany, the analysis shows that only $39 \%$ of all tasks are outsourced by Germany.

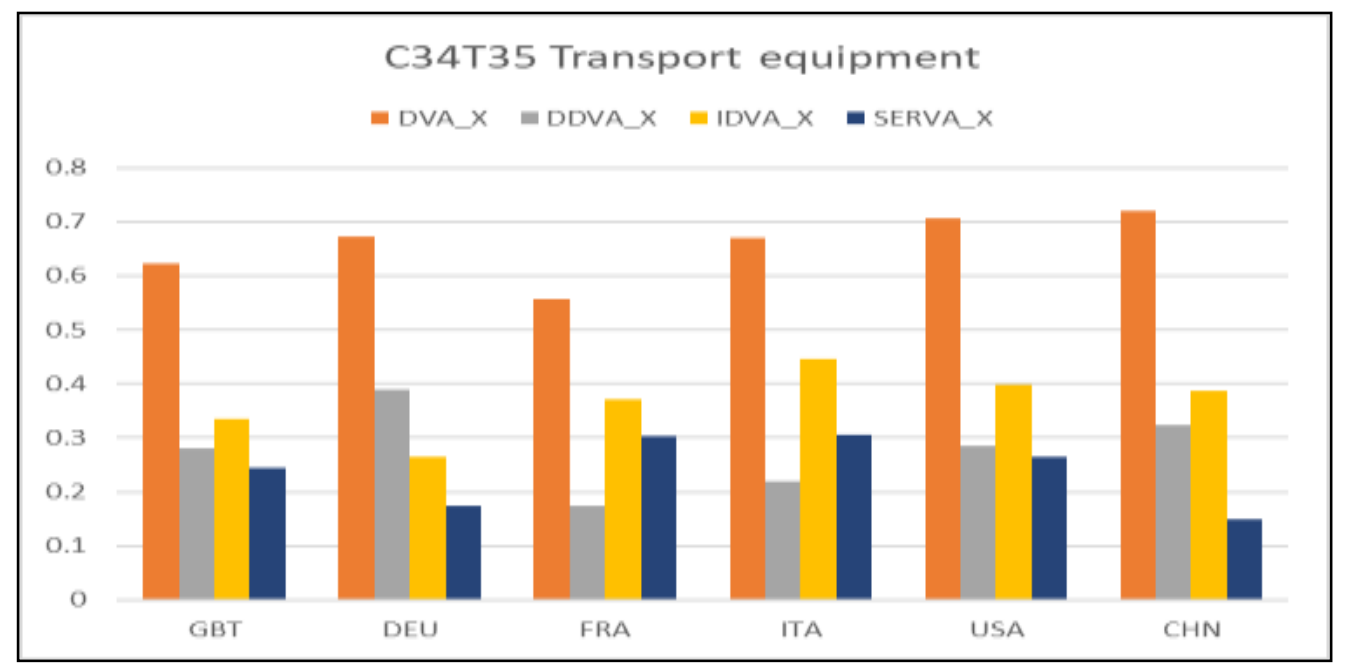

Figure 3. Transport equipment: selected TiVA indicators, 2014

Notes: DVA_X: domestic value added embodied in sectoral exports; DDVA_X: direct domestic value added from the exporting industry; IDVA_X: indirect sources of domestic value-added (outsourced to other domestic sectors); SERVA_X: share of services value-added (domestic and foreign) in total sectoral exports.

Source: Author's calculations based on OECD TiVA Nowcasts. 
For the UK, most imported content comes from the EU countries. The UK imports $67 \%$ of total inputs used from the EU for its automobile sector. Car manufacturers, such as Nissan, BMW, PSA (owner of Vauxhall), and Jaguar Land Rover, with production facilities in the UK, expect an adverse impact of Brexit on their UKbased operations. Manufacturing data shows that UK car production fell by 47\% during April 2019 in the expectation that the UK would leave the EU suggesting that the effect of Brexit talks was being felt. The UK's biggest automaker, Jaguar Land Rover, announced 4,500 layoffs, which is more than a tenth of its workforce.

\section{Estimates on UK Losses when Exports lose Competitiveness}

Frictions reduce competitiveness of domestic firms when converted at international prices (Escaith, 2017). After the UK's departure from the EU, tariffs and non-tariff barriers will lead to trade costs from tariffs and an administrative burden from customs clearing formalities and delays, and differences in standards and regulations between the UK and EU (Cappariello, 2017). Brexit and higher trade costs, which include higher applied tariffs, transportation and insurance costs, non-tariff measures (NTMs) i.e. border taxes and fees, will increase costs given the intermediate goods are imported and re-exported further downstream for additional processing before reaching the consumers. Estimating losses due to a lack of cost competitiveness is critical after Brexit when we examine this from a supply chain perspective. Strategies, to address lost export competitiveness could include duty drawbacks (the exporter can redeem the value of the tariff duties and other indirect taxes paid on inputs used for exports) and free export processing zones (industrial parks installed in fiscal enclaves). Assumes alternative duty-drawback scenarios for UK exporters we simulate the following scenarios:

$>$ Full duty draw-back allowed on imported EU inputs to all domestic producers associated with the valuechain;

$>$ Partial drawback, i.e. only direct exporters, i.e. first and second-tier domestic suppliers that cannot benefit from draw-back schemes, are allowed duty draw-back on imported inputs, i.e. cost of imported inputs in export price;

$>$ Exclude any duty draw-back on UK exports to EU.

Four additional scenarios with non-tariff measures ranging from $0 \%, 2.5 \%, 5 \%$ to $10 \%$ are simulated to determine the degree to which the pound sterling would have to be devaluated to offset the negative effect on competitiveness. Escaith (2017) suggests that the magnification effect of trade costs in supply chain production settings requires compensatory devaluation to preserve the current level of export competitiveness. For UK exporters to remain competitive, an option is to lower the factory-gate price in Euros accomplished through the devaluation of Pound Sterling. Given the domestic share of value-added is always lower than 1 , a $1 \%$ increase in trade costs will be compensated by devaluation greater than $1 \%$. For example, in the case of transport equipment, the direct domestic value-added share is $28 \%$ and indirect value-added share is $34 \%$. A 9\% increase in EU tariff on UK exports requires a devaluation of the pound by 14.5\% (9\%/62\%) to remain competitive. Thus, the lower the domestic share of value-added, the higher the devaluation will need to be to compensate for increase in trade costs. Table 5 provides estimates of the devaluation required for various sectors to retain the competitiveness of three important UK export sectors - automobiles, chemicals and electronics.

Table 5. Compensatory devaluation required to mitigate the effect of increased trade costs with EU27

\begin{tabular}{|c|c|c|c|c|c|c|c|c|c|c|c|c|}
\hline Duty-drawback allowed & \multicolumn{4}{|c|}{ Full drawback } & \multicolumn{4}{|c|}{ Partial drawback } & \multicolumn{4}{|c|}{ No drawback } \\
\hline & \multicolumn{4}{|c|}{ Tariff and NTM } & \multicolumn{4}{|c|}{ Tariff and NTM } & \multicolumn{4}{|c|}{ Tariff and NTM } \\
\hline NTM (ad-valorem equivalent) & $0 \%$ & $2.50 \%$ & $5 \%$ & $10 \%$ & $0 \%$ & $2.50 \%$ & $5 \%$ & $10 \%$ & $0 \%$ & $2.50 \%$ & $5 \%$ & $10 \%$ \\
\hline Transport equipment & 14.5 & 18.5 & 22.5 & 30.6 & 15.3 & 19.7 & 24.1 & 33.0 & 16.6 & 21.6 & 26.7 & 36.8 \\
\hline $\begin{array}{l}\text { Chemicals and non-metallic mineral } \\
\text { products }\end{array}$ & 4.2 & 8.1 & 12.1 & 19.9 & 4.9 & 9.1 & 13.3 & 21.8 & 6.0 & 10.8 & 15.6 & 25.1 \\
\hline $\begin{array}{l}\text { Computer, Electronic and optical } \\
\text { equipment }\end{array}$ & 2.6 & 6.1 & 9.5 & 16.4 & 2.9 & 6.5 & 10.1 & 17.3 & 3.5 & 7.4 & 11.3 & 19.0 \\
\hline
\end{tabular}

Note: Full drawback: all firms in the domestic supply chain can be reimbursed for the additional trade cost when exporting; Partial: only direct exporters can claim draw-back; None: no drawback allowed.

Source: Authors' estimates, based on TiVA 2014 data and Cappariello (2017) 
After the UK's departure from the EU, for the transport equipment sector to remain competitive in the EU, devaluation will be required to compensate for additional tariffs as much as $15-17 \%$. The devaluation will, however, depend on any draw-back procedures that the UK may put in place to alleviate the burden of trade costs for exporters. If non-tariff barriers result in 5\% additional costs, currency devaluation of $23-27 \%$ will be needed to preserve UK automobile exporters' competitiveness into the EU. Should those costs increase by $10 \%$, the likely devaluation could be to be as high as $37 \%$. Without devaluation, the automotive manufacturing sector will be severely impacted and existing supply chain arrangements will be disrupted.

The impact of import tariffs on demand depends on price elasticity (Kee and Nicita, 2017). Given price elasticity for the transport equipment sector is low, this implies that the impact of tariffs on prices may not dramatically affect final demand. On the other hand, NTMs will be a key factor after the UK leaves the EU on 31 December 2020, and the precise incidence of NTMs will be difficult to assess because border delays are likely to create uncertainties in delivery time - a critical parameter in supply chain management for car makers. While it may be possible for the exporters to pass additional costs to EU customers in the short term, overall competitiveness of UK export will suffer in the long run. This suggests that lower competitiveness may deflect future investments to other countries, as already seen in announcements by car manufacturers (e.g. Honda's decision to move from Swindon and Nissan from Sunderland) to switch current production base from the UK.

\section{Conclusion}

Globalisation and the economic interconnectedness has been hit by Brexit and the pandemic risks delivering a knockout blow. As part of the EU single market, automobile manufacturers in the UK made locational decisions based on supply chain logistics that did not include trade costs among EU members. This made the automotive supply chains continentally integrated and the UK's automotive industry facilitated manufacturing through the embedding of intermediate inputs from around the EU into finished car exports. Future UK-EU trade partnership negotiations are ongoing but concerns exist on the shape of UK-EU economic partnership and whether there might be barriers to trade should the UK leave without any deal or a shallow agreement. Lack of clear future EU-UK relationship could lead to UK-EU supply chain disruptions such that trade costs could increase from the imposition of tariffs and NTBs, given the automotive sector is heavily integrated with European automobile value chains. The UK's departure from the single market will also bring changes to the rules of origin checks, customs delays, tariffs and, most of all, diverging regulations will harm automotive production. Given the reliance on in just-in-time delivery, any form of border delays can be expected to have far reaching effects.

A virus-induced backlash against globalisation is inevitable and this, together with Brexit, is likely to bring major changes to the UK's trade landscape. The supply chain disruptions from COVID-19 have accelerated calls for countries and trading blocs to ensure they have sufficient capacity at home. In the short term, reconfiguring supply chains may be difficult given that these are based on complex contractually binding inter-industrial arrangements that limit the freedom of firms regarding their choice of inputs (Baldwin and Evenett, 2020). Uncertainty about the future direction of trade policy as well as the future of technologies relying on fossil fuels have led to the automobile sector postponing strategic capital investment decisions, while decisions that cannot be postponed are likely to be biased in favour of non-UK locations. High transaction costs could lead firms to review supply chains arrangements and possibly to switch input suppliers in the long term. Given companies examine cost levels and service levels for nodes in their supply chains if transaction costs rise, firms may reconsider and review the current or planned node locations in the UK, as has already been the case with automobile manufacturing firms such as Honda, Nissan and BMW, among others. If unfettered access to the EU market has been central to the location decisions of automobile manufactures, changes in supply chain costs will be an important part of what the automotive sector decides.

One possible option to safeguard UK export competitiveness is introducing a comprehensive draw-back scheme and exchange rate adjustment, i.e. compensatory devaluation, but given most components are sourced from mainland Europe and the share of value added is low, a higher exchange rate adjustment will be required due to the magnification effect. Given the UK's departure from the EU single market is imminent on 31 December 2020 duty drawback schemes could support offsetting higher production costs, but any such measures are unlikely to replace the benefits of the current duty-free access under the present arrangement. In the past, the gains from single market membership were higher in the absence of tariff and non-tariff barriers 
which led to structuring of automotive sector's value chains. These gains cannot be ignored in the new UKEU trade arrangement and to ensure the survival of the automotive industry an agreement on the future trade options is imperative before the UK leaves the EU on 31 December 2020.

Funding: self-funded.

Author Contributions: conceptualization, Hubert Escaith, Sangeeta Khorana, William Kerr; data curation, Hubert Escaith; formal analysis, Hubert Escaith, Sangeeta Khorana; funding acquisition, Hubert Escaith, Sangeeta Khorana, William Kerr; investigation, Hubert Escaith, Sangeeta Khorana, William Kerr; methodology, Hubert Escaith; project administration, Hubert Escaith, Sangeeta Khorana, William Kerr; resources, Hubert Escaith, Sangeeta Khorana, William Kerr; software, Hubert Escaith, Sangeeta Khorana, William Kerr; supervision, Hubert Escaith, Sangeeta Khorana, William Kerr; validation, Hubert Escaith, Sangeeta Khorana, William Kerr; visualization, Hubert Escaith, Sangeeta Khorana, William Kerr; writing original draft, Hubert Escaith, Sangeeta Khorana, William Kerr; writing - review \& editing, William Kerr.

\section{References}

1. ACEA (2019). European Automobile Manufacturers Association. Available at: https://www.acea.be/uploads/news documents/Brexit-facts figures March 2019.pdf.

2. Acemoglu, D., V.M. Carvalho, A. Ozdaglar and A. Tahbaz-Salehi (2012). The Network Origins of Aggregate Fluctuations, Econometrica, 80 (5), 1977-2016. DOI: https://doi.org/10.3982/ECTA9623.

3. Ahmad, N. (2019). Improving the accounting frameworks for analyses of global value chains, in Global Value Chain Report 2019: Technological Innovation, Supply Chain Trade, and Workers in a Globalized World, Chapter 8; WTO. Available at: https://www.oecd.org/dev/Global-Value-Chain-DevelopmentReport-2019-Technological-Innovation-Supply-Chain-Trade-and-Workers-in-a-Globalized-World.pdf.

4. Ali, S. and U. Durdash (2011). The Rise of Trade in Intermediates: Policy Implications, International Economic Bulletin, Washington: Carnegie Endowment for International Peace, February. Available at: https://voxeu.org/article/rise-trade-intermediates-policy-implications.

5. Ali-Yrkkö, J. \& Kuusi, T (2019). Brexit and Indirect Impact Routes through Global Value Chains. ETLA Report No 89. Available at: https://pub.etla.fi/ETLARaportit-Reports-89.pdf.

6. Antràs, $\mathrm{P}$ and A. de Gortari (2018). On the Geography of Global Value Chains, manuscript Cambridge: Harvard University. Available

at: https://scholar.harvard.edu/files/antras/files/conceptual aspects gvcs.pdf.

7. Baldwin, R. (2006). Globalisation: The Great Unbundling(s). Helsinki, Finland: The Economic Council of Finland, Prime Minister's Office. Available at: https://pdfs.semanticscholar.org/ac4f/a1e76d01d9f7c9f991b352abdb60d2a15e4f.pdf.

8. Baldwin, R. (2012). Global Supply Chains: Why They Emerged, Why They Matter, and Where They are Going, CEPR Discussion Papers, no. 9103, London: Centre for Economic Policy Research. Available at: https://econpapers.repec.org/paper/cprceprdp/9103.htm.

9. Baldwin, R. and S. Evenett (2020). COVID-19 and Trade policy: Why Turning Inward won't work? VOX-CEPR Policy portal. Available at: https://voxeu.org/content/covid-19-and-trade-policy-whyturning-inward-won-t-work.

10. Baldwin, R.E. and J. Lopez-Gonzalez (2013). Supply-Chain Trade: A Portrait of Global Patterns and Several Testable Hypotheses, NBER Working Paper 18957, Cambridge: National Bureau of Economic Research. Available at: https://papers.ssrn.com/sol3/papers.cfm?abstract_id=2251702.

11. Baldwin, R., and A. Venables (2010). Spiders and Snakes: Offshoring and Agglomeration in the Global Economy, NBER Working Paper No. 16611, Cambridge: National Bureau of Economic Research. Available at: https://www.nber.org/papers/w16611.pdf.

12. Bailey, D and L. Propris De (2017), Brexit and the UK Automotive Industry, National Institute of Economic Review, 242 (1), 51-59. DOI: https://doi.org/10.1177/002795011724200114.

13. Bigsten, A., P. Collier, S. Dercon, M. Fafchamps, B. Gauthier, J. W. Gunning, A. Oduro, R. Oostendorp, C. Patillo, M. Soderbom, F. Teal, and A. Zeufack (2000). Contract Flexibility and Dispute Resolution in African Manufacturing, Journal of Development Studies, 36 (4), 1-17. DOI: $10.1080 / 00220380008422635$.

14. Blanchard, E.J., C.P. Bown and R.C. Johnson (2016). Global Supply Chains and Trade Policy, Technical report, Cambridge: National Bureau of Economic Research. Available at: https://site.stanford.edu/sites/g/files/sbiybj8706/f/bbj-june2016.pdf. 
15. Borchert, I. and N. Tamberi (2018). Brexit and Regional Services Exports: A Heat Map Approach. UKTPO Briefing Paper 14, UK Trade Policy Observatory, Brighton: University of Sussex. Available at: https://blogs.sussex.ac.uk/uktpo/files/2018/01/Briefing-paper-14-Heatmap-final.pdf.

16. Borgatti, S.P. (2005). Centrality and Network Flow. Social Networks, 27 (1), 55-71. Available at: http://www.analytictech.com/borgatti/papers/centflow.pdf.

17. Brakman, S., H. Garretsen and T. Kohl (2018). Consequences of Brexit and Options for a 'Global Britain',
Papers
in Regional
Science,
97 ,
$55-72$.
Available
at: https://onlinelibrary.wiley.com/doi/pdf/10.1111/pirs.12343

18. Cappariello, R. (2017). Brexit: Estimating Tariff Costs for EU Countries in a New Trade Regime with the UK, Occasional Paper 381, Rome: Banca d'Italia. Available at: https://ideas.repec.org/p/bdi/opques/qef_381_17.html.

19. Cappariello, R., Damjanovic, M., Mancini, M. and Vergara Caffarelli, F. (2018). EU-UK Global Value Chain Trade and the Indirect Costs of Brexit (November 6). Bank of Italy. Available at: http://www.bancaditalia.it/pubblicazioni/qef/2018-0468/QEF_468_18.pdf.

20. Chen, W., B. Los, P. McCann, R. Ortega-Argilés, M. Thissen and F. van Oort (2018). The Continental Divide? Economic Exposure to Brexit in Regions and Countries on Both Sides of The Channel', Papers in Regional Science, 97(1), 25-54. DOI: https://doi.org/10.1111/pirs.12334.

21. Clarke, H.D., M.J. Goodwin, M. Goodwin and P. Whiteley (2017), Brexit, Cambridge: Cambridge University Press. DOI: https://doi.org/10.1017/9781316584408.

22. Coe, N.M. and Yeung, H.W.C. (2015). Global Production Networks: Theorizing Economic Development in an Interconnected World, Oxford: Oxford University. DOI: 10.1093/acprof:oso/9780198703907.001.0001.

23. Department for International Trade (2019). UK Trade in Numbers, February, Available at: https://assets.publishing.service.gov.uk/government/uploads/system/uploads/attachment_data/file/83678 7/190924_UK_trade_in_numbers_full_web_version_final.pdf.

24. Dhingra, S., H. Huang, G. Ottaviano, J. Paulo Pessoa, T. Sampson, and J. Van Reenen (2017). The costs and benefits of leaving the EU: trade effects, Economic Policy, 32, 651-705. DOI: https://doi.org/10.1093/epolic/eix015.

25. Escaith, H (2014). 'Mapping Global Value Chains and Measuring Trade in Tasks', in Asia and Global Production Networks: Implications for Trade, Incomes and Economic Vulnerability, edited by B Ferrarini and D Hummels, Asian Development Bank (Manila) and Edward Elgar Publishing (Cheltenham and Northampton). Available at: https://www.adb.org/publications/asia-and-global-production-networksimplications-trade-incomes-and-economic-vulnerability.

26. Escaith, H. (2017). Accumulated Trade Costs and Their Impact on the Development of Domestic and International Value Chains. In Global Value Chain Development Report 2017: Measuring and Analyzing the Impact of GVCs on Economic Development, Washington: World Bank, IDE-JETRO, OECD, Research Center of Global Value Chains (UIBE) and the WTO, pp. 97-117. Available at: https://www.wto.org/english/res e/booksp e/gves report 2017.pdf

27. Gasiorek, M., I. Serwicka and A. Smith (2019). Which Manufacturing Industries and Sectors are Most Vulnerable to Brexit?, World Economy, 42 (1), 21-56. DOI: https://doi.org/10.1111/twec.12757.

28. Gereffi, G., J. Humphrey and T. Sturgeon (2005) The Governance of Global Value Chains, Review of International Political Economy, 12: 78-104. DOI: 10.1080/09692290500049805.

29. Grossman, G.M. \& Rossi-Hansberg, E. (2008). Trading tasks: A simple theory of offshoring, American Economic Review, 98(5): 1978-1997. DOI: 10.1257/aer.98.5.1978.

30. H M Government (2017). Building a Britain Fit for the Future, Industrial Strategy White Paper. Available at: https://assets.publishing.service.gov.uk/government/uploads/system/uploads/attachment data/file/664563/ind ustrial-strategy-white-paper-web-ready-version.pdf.

31. Hobbs, J.E. (1996). A Transaction Cost Approach to Supply Chain Management, Supply Chain $\begin{array}{lllll}\text { Management, } & 1 & \text { (2), } & \text { 15-27. }\end{array}$ https://www.emerald.com/insight/content/doi/10.1108/13598549610155260/full/html?skipTracking=true.

32. Hummels, D., J. Ishii, and K-M. Yi (2001). The Nature and Growth of Vertical Specialization in World Trade, Journal of International Economics, 54 (1), 75-96. Available at: http://www.sciencedirect.com/science/article/pii/S0022-1996(00)00093-3.

33. Ignatenko, A., Raei, F. and Mircheva, B. (2019). Global Value Chains: What are the Benefits and Why Do Countries Participate? IMF Working Paper No: WP/19/18. Available at: https://link.springer.com/chapter/10.1007\%2F978-3-030-43189-1_3. 
34. Ijtsma, P., P. Levell, B. Los and M.P. Timmer (2018). The UK's Participation in Global Value Chains and Its Implications for Post-Brexit Trade Policy. Fiscal Studies, 39 (4), 651-683. DOI: https://doi.org/10.1111/1475-5890.12176.

35. Johnson, R., and G. Noguera (2012). Accounting for Intermediates: Production Sharing and Trade in Value Added, Journal of International Economics, 86, 224-236. DOI: 10.1016/j.jinteco.2011.10.003.

36. Kano, L., Tsang, E.W.K. \& Yeung, H.W. (2020). Global value chains: A review of the multi-disciplinary literature, Journal of International Business Studies 51, 577-622. DOI: 10.1057/s41267-020-00304opinion-files/9071.pdf.

37. Keane, J. (2014). Global Value Chain Analysis: What's New, What's Different, What's Missing?, London: Overseas Development Institute, Available at: https://www.odi.org/sites/odi.org.uk/files/odiassets/publications-.

38. Kee, H.L. and A. Nicita (2017). Short-Term Impact of Brexit on the United Kingdom's Export of Goods, World Bank Policy Research Working Paper 8195, Washington: World Bank. Available at: https://documents.worldbank.org/en/publication/documentsreports/documentdetail/164821505330746382/short-term-impact-of-brexit-on-the-united-kingdomsexport-of-goods.

39. Koopman, R., Z. Wang, and S-J. Wei (2014). Tracing Value-Added and Double Counting in Gross Exports, American Economic Review, 104: 459-494. DOI: 10.1257/aer.104.2.459.

40. Lobao, J. and Santos, S. (2019). Stock Market Reaction to Brexit's Announcements: Evidence from a Natural Experiment, Global Economy Journal, 19(3), $1950018 . \quad$ DOI: https://doi.org/10.1142/S2194565919500180.

41. Milberg, W. and Winkler, D. (2013). Outsourcing Economics: Global Value Chains in Capitalist Development. Cambridge: Cambridge University Press. Available at: https://globalvaluechains.org/publication/outsourcing-economics-global-value-chains-capitalistdevelopment.

42. Miroudot, S. (2016). Services in Global Value Chains: From Inputs to Value-Creating Activities, Trade Policy Paper, Paris: Organisation for Economic Co-operation and Development (OECD). DOI: 10.1787/465f0d8b-e.

43. Miroudot, S. D. Rouzet and F. Spinelli (2013). Trade Policy Implications of Global Value Chains: Case Studies, OECD paper TAD/TC/WP(2013)13. DOI: https://doi.org/10.1787/5k3tpt2t0zs1-en.

44. Nadvi, K. and R. Horner (2018). Global Value Chains and the Rise of the Global South: Unpacking Twenty-first Century Polycentric Trade, Global Networks, 18 (2), 207-237. DOI: https://doi.org/10.1111/glob.12180.

45. Nielson, J. (2014). Value Chains, Neoliberalism and Development Practice: The Indonesian Experience, Review of International Political Economy, 24 (1), 38-69. DOI: https://doi.org/10.1080/09692290.2013.809782.

46. Nolan, P. and J. Zhang (2010). Global Competition After the Financial Crisis, New Left Review, 64, $97-$ 108. Available at: https://newleftreview.org/issues/II64/articles/peter-nolan-jin-zhang-globalcompetition-after-the-financial-crisis.

47. Organisation for Economic Co-operation and Development (OECD) (2013). 'Mapping Value Chains,' Working Party of the Trade Committee TAD/TC/WP/RD (2013), 3 December, The OECD Conference Centre, $\quad$ Paris. Available http://www.oecd.org/officialdocuments/publicdisplaydocumentpdf/?cote=TAD/TC/WP(2012)6/FINAL \&docLanguage $=$ En .

48. OECD (2016). The Economic Consequences of Brexit: A Taxing Decision," Economic Policy Papers 16 , OECD. Available at: https://www.oecd.org/unitedkingdom/The-Economic-consequences-of-Brexit-27april-2016.pdf.

49. Portuese, A. (2018). Towards a Meta Cost-benefit Analysis: The Case of Brexit, Journal of International Law and Trade Policy 19 (1): 30-54. DOI: 10.22004/ag.econ.276242.

50. Pisani, M. and F. V. Caffarelli (2018). What will Brexit mean for the British and euro-area economies? A model-based assessment of trade, Economic working paper: 1163, Bank of Italy, Directorate General for Economics, Statistics and Research. Available at: https://www.bancaditalia.it/pubblicazioni/temidiscussione/2018/2018-1163/index.html?com.dotmarketing.htmlpage.language $=1$.

51. Protts, J. (2016). Potential post-Brexit Tariff Costs for EU-UK trade, Civitas, 23 October, Available at: http://www.civitas.org.uk/content/files/potentialpostbrexittariffcostsforeuuktrade.pdf. 
52. Rakita, B., Madić, V. and Marković, D. (2017). Competitive Strategies of Late Followers in Auto Industry: Case Study Hyundai-Kia. Industrija, 45(1), 121-146. Available at: chromeextension://ohfgljdgelakfkefopgklcohadegdpif/https://pdfs.semanticscholar.org/0da5/5f2f065ae0fe1d20bd10f 922a96a58e4d93d.pdf? ga=2.105891780.636430942.1598807595-1201350362.1598807595.

53. Rojas-Romagosa, H. (2016). Trade effects of Brexit for the Netherlands, CPB Background Document June, $C P B$ - Netherlands Bureau for Economic Policy Analysis. Available at: chromeextension://ohfgljdgelakfkefopgklcohadegdpjf/https://www.cpb.nl/sites/default/files/omnidownload/CPBBackgroud-Document-June-2016-Trade-effects-of-brexit-for-the-netherlands.pdf.

54. Ruddick, G. (2017). Hard Brexit 'Could Increase Cost of Making a Car by £2,400', The Guardian, 20 March, Available at: https://www.theguardian.com/business/2017/mar/20/hard-brexit-cost-car-uk-wto-rules.

55. Shende, V. (2014). Analysis of Research in Consumer Behavior of Automobile Passenger Car Customer. International Journal of Scientific and Research Publications, 4(3), 17-34. Available at: chromeextension://ohfgljdgelakfkefopgklcohadegdpjf/http://www.ijsrp.org/research-paper-0214/ijsrp-p2670.pdf.

56. Timmer, M. P., A. Azeez Erumban, B. Los, R. Stehrer, and G. J. de Vries (2014). Slicing Up Global Value Chains, Journal of Economic Perspectives, 28 (2), 99-118. Available at: https://www.aeaweb.org/articles?id=10.1257/jep.28.2.99.

57. UN Conference on Trade and Development (UNCTAD) (2013). Implications of Global Value Chains for Trade, Investment, Development, and Jobs, UNCT. Available at: chromeextension://ohfgljdgelakfkefopgklcohadegdpif/https://unctad.org/en/PublicationsLibrary/unctad_oecd_wto_2 013d1_en.pdf.

58. Vandenbussche, H, W. Connell and W. Simons (2017). Global Value Chains, Trade Shocks and Jobs: An Application to Brexit, CEPR Discussion paper 12303, London: Centre for Economic Policy Research. Available at: https://cepr.org/active/publications/discussion_papers/dp.php?dpno=12303.

59. World Bank; World Trade Organization (2019). Global Value Chain Development Report 2019: Technological Innovation, Supply Chain Trade, and Workers in a Globalized World, Washington, D.C.: World Bank Group. Available at: https://www.worldbank.org/en/topic/trade/publication/global-value-chaindevelopment-report-2019.

60. World Bank (2020). World Development Report: 2020 Trading for Development in the Age of Global Value Chains, World Bank, Washington, DC. Available at: https://www.worldbank.org/en/publication/wdr2020.

61. WTO (2017). World Trade Report, 2017: Trade, Technology and Jobs, Geneva: World Trade Organization. Available at:

chromeextension://ohfgljdgelakfkefopgklcohadegdpjf/https://www.wto.org/english/res e/booksp e/world trade rep ort17_e.pdf.

62. Wyman, O. (2016). The Impact of the UK's Exit from the EU on the UK-based Financial Services Sector. Available at: chromeextension://ohfgljdgelakfkefopgklcohadegdpjf/https://www.oliverwyman.com/content/dam/oliverwyman/global/en/2016/oct/OW\%20report_Brexit\%20impact\%20on\%20Uk-based\%20FS.pdf

63. Xu, J. and Liu, X. (2018). Technology is Changing What a Premium Brand Looks Like. Harvard Business Review, 96(5), 2-5. Available at: https://hbr.org/2018/05/technology-is-changing-what-a-premiumautomotive-brand-looks-like. 